\title{
Legal Doctrinal Scholarship and Interdisciplinary Engagement
}

\author{
Matyas Bodig*
}

\begin{abstract}
The paper offers a legal theoretical analysis of the disciplinary character of the contemporary practice of legal scholarship. It is assumed that the challenges of interdisciplinary engagement are particularly revealing about the nature of legal scholarship. The paper argues for an understanding of legal scholarship that revolves around cultivating doctrinal knowledge about law. Legal scholarship is characterised as a normative and interpretive discipline that offers an internalist and non-instrumentalist perspective on law. The paper also argues that interdisciplinary engagement is sometimes necessary for legal scholars because some concepts and ideas built into the doctrinal structures of law cannot be made fully intelligible by way of pure normative legal analysis. This point is developed with the help of an epistemological clarification of doctrinal knowledge and anchored in an account of the practice of legal scholarship. The paper explores the implications of this account by way of analysing three paradigms of interdisciplinary engagement that respond to distinctive challenges facing legal scholarship: (1) understanding better the extra-legal origins of legal ideas, (2) managing discursive encounters that can generate frictions between disciplinary perspectives, and (3) building the knowledge base to handle challenge of validating policy initiatives that aim at changing the law. In different ways, all three challenges may require legal scholars to build competence in other disciplines. The third paradigm has particular relevance for understanding the methodological profile of legal scholarship. Legal scholarship is the only discipline with specific focus on how the social environment affects the doctrinal structures of law.
\end{abstract}

Keywords: Doctrinal knowledge, interdisciplinary scholarship, interpretivism, internalism, non-instrumentalism

\section{Introduction}

It is fair to assume that there is significant methodological uncertainty around the very character of legal doctrinal scholarship. ${ }^{1}$ It sometimes manifests itself in a sense

* Dr Matyas Bodig is Senior lecturer at the University of Aberdeen School of Law, Aberdeen, UK.

1. I will use the terms 'legal doctrinal scholarship' and 'legal scholarship' interchangeably in this analysis. of crisis among legal scholars. ${ }^{2}$ Even though it is not particularly difficult to account for the characteristic activities of doctrinal scholars, it is much less obvious what qualifies their 'doctrinal' research as genuine, creditable scholarship. The sense of uncertainty within legal scholarship is often matched by a lack of understanding of its character on the part of other disciplines. Memorably, in Becher and Trowler's seminal analysis on the culture of disciplines, legal scholarship is depicted as a 'soft applied science', and it is made to look quite marginal on the academic landscape. ${ }^{3}$ I believe that addressing the tensions around legal scholarship is one of the exciting challenges for contemporary legal theory. The present analysis uses the resources of legal theoretical reflection to address issues about the disciplinary character of legal scholarship. I hope to be able to shine some light on the specific epistemological merits of a doctrinal discipline about law. I am not one of those who seek a way of putting to rest the uncomfortable methodological challenges by reimagining legal scholarship - often by giving up on its doctrinal orientation. ${ }^{4}$

The reasons why this crisis of identity and a sense of marginalisation plague legal scholarship are, of course, multifarious. Some of them are related to the gradual shift of the academic landscape in the nineteenth and twentieth centuries (and the emergence of the modern social sciences in particular) that was rather unfavourable for legal scholarship. One may even make the case for the view that we have seen the emergence of an imagery of disciplinarity (that revolves around processing facts, developing general theories, and testing hypotheses) that is not quite fitting for legal scholarship. Some further reasons may be related to the disciplinary culture of legal scholarship. In a discipline where the

2. 'In the past 20 or so years the intellectual coherence of law as an academic discipline has increasingly been called into question'. S. Bartie, 'The Lingering Core of Legal Scholarship', 30 Legal Studies 345, at 345 (2010). See also M. Tushnet, 'Legal Scholarship: Its Causes and Cure', 90 Yale Law Journal 1205 (1981). E.L. Rubin, 'Law and the Methodology of Law', Wisconsin Law Review 521, at 521 (1997). M. van Hoecke and F. Ost, 'Legal Doctrine in Crisis: Towards European Legal Science', 18 Legal Studies 197 (1998). J.M. Smits, 'Redefining Normative Science: Towards an Argumentative Discipline', in F. Coomans, F. Grünfeld, \& M.T. Kamminga (eds.), Methods of Human Rights Research (2009) 45, at 47.

3. T. Becher and P.R. Trowler, Academic Tribes and Territories: Intellectual Enquiry and the Culture of Disciplines (2nd ed. 2001), at 31.

4. See G. Samuel, 'Interdisciplinarity and the Authority Paradigm: Should Law Be Taken Seriously by Scientists and Social Scientists', 36 Journal of Law and Society 431, at 449 (2009). G. Samuel, 'Is Law Really a Social Science?: A View from Comparative Law', 67 Cambridge Law Journal 288 , at 315 (2008). 
scholars often see themselves as 'academic lawyers' (rather than academics per se), there is no obvious place for deeper methodological reflection and explicit methodological controversies on the disciplinary character of law. It is no surprise that this may make adaptation to a changing social and academic environment slow, halting and disorienting.

This suggests that addressing the issues of disciplinary character and practice of legal scholarship requires us to raise deeper and broader questions - some of which go beyond the scope of this analysis. I do not deal here with issues of disciplinary culture in any detail, and I do not set out to develop a concept of disciplinarity that is more fitting for legal scholarship - even though I acknowledge that some of my claims are in need of validation from a broader and more ambitious investigation into the nature of legal scholarship. What I can undertake here is an aspect of understanding better the character of legal doctrinal scholarship as it is practised today. I reflect on the problems of interdisciplinary engagement in legal scholarship. I find them particularly revealing about the character of legal scholarship.

I specifically look at interdisciplinary engagement from the perspective of legal scholarship. I do not ask how engagement with legal scholarship might benefit other disciplines. ${ }^{5}$ I ask what may make interdisciplinary engagement necessary for legal scholars in certain situations. ${ }^{6}$ Nor do I explore the specific dynamics of interdisciplinary cooperation (e.g. in the context of particular research projects). What I am more interested in is the necessity for legal scholars of building some competence in other disciplinary perspectives. What makes it necessary for legal scholars to understand what related disciplines have to say about a particular epistemic object and to try to solve the methodological puzzle of accommodating in their work what they learn from other disciplines?

It is important to emphasise that my analysis is rooted in a particular conception of legal doctrinal scholarship that I have developed elsewhere ${ }^{7}$ and keep developing. It confers on legal scholarship the function of cultivating doctrinal knowledge about law. This conception profoundly determines the way I perceive the problem of

5. Of course, some ways in which other disciplines can benefit from engaging with legal scholarship are not hard to figure out. For example, other disciplines (like sociology and political science) often need to fight the intuition that doctrinal reasoning in important judicial decisions is just window-dressing. See E.H. Tiller and F.B. Cross, 'What is Legal Doctrine?', 100 Northwestern University Law Review 517 (2006).

6. I note that, for the sake of simplicity, I completely set aside the problem of interdisciplinary engagement between doctrinal disciplines (like law and theology). That raises significantly different methodological issues (and it does not seem to shape the contemporary practice of legal scholarship significantly anyway). What I deal with is the methodological challenge of interdisciplinary engagement with non-doctrinal disciplines (like economics, sociology, political science, etc.). This is what brings into sharp relief the key features of legal scholarship - its normative, interpretive, and internalist character.

7. See M. Bódig, 'Legal Theory and Legal Doctrinal Scholarship', 23 Canadian Journal of Law and Jurisprudence 483 (2010); M. Bódig, 'Doctrinal Devices, Legal Expertise, Empirical Knowledge, and the Doctrinal Structures of Causation Jurisprudence', 1 Theory and Practice of Legislation 469 (2013). interdisciplinary engagement in legal scholarship. However, I can provide only a brief (and slightly underreflected) overview of this account here. (The next section will be dedicated to it.) I leave many implications of the salient features of legal scholarship on one side (e.g. I do not reflect on the, otherwise hugely important, functional connection with the legal profession and legal education). This paper can only have a narrow focus and relatively limited ambitions.

As to the substantive points of the paper, I argue that we can identify a distinctive rationale for interdisciplinary engagement in legal scholarship. Due to certain features of law (that I address below and especially in the fourth section), cultivating doctrinal knowledge about law requires legal scholars to work with concepts and ideas that cannot be made fully intelligible through mere normative legal analysis. Also, doctrinal knowledge exists in a state of permanent renewal due to the extralegal information flowing into legal procedures and policy debates. In a very real sense, interdisciplinary engagement becomes a vital aspect of maintaining and improving the ability of legal scholarship to cultivate doctrinal knowledge. However, it does not mean that there is one general pattern to the methodological challenge interdisciplinary engagement poses. I believe that it is more appropriate to think of interdisciplinary engagement in terms of a series of paradigms that originate from particular (but recurrent) methodological challenges facing legal scholars and that are related to different aspects of the work legal scholars do. I do not set out to identify all such paradigms. I will explore below three of them. It seems to me that they are the ones we need to elucidate and substantiate the points I formulate about the legal scholarship.

I have mentioned above that I do not seek to overcome the methodological uncertainties by reimagining legal scholarship. In an important sense, the present analysis is part of a broader argument about the way legal scholarship can become more assured about its disciplinary identity. Even though there is a very real sense of uncertainty about its role and character, legal scholarship has also shown remarkable resilience and staying power. Occasional attempts to reconstitute it on the model of, say, the social sciences were frustrated time and again. It may be a sign of the viability of a doctrinal discipline about law. I am convinced that once we subject the epistemological profile of legal scholarship to more thorough theoretical scrutiny, we find there a methodological paradigm that must be an integral part of the academic landscape. There are epistemic gains to be realised by doctrinal scholarship that are ripe for academic study and that are not accessible to other disciplines. Raising questions about interdisciplinary engagement in legal scholarship is one of the pathways towards that more thorough theoretical scrutiny.

Even though it is part of my ambitions to raise the profile of existing legal scholarship, it does not mean that I advocate the sort of conservatism about the practice of legal scholarship that would leave everything as it is. Even though legal scholarship is built on an eminently 
viable epistemological paradigm (that I will outline in section three), currently it is not in the best shape to fulfil its potentials. Significant changes to the practice of legal scholarship are inevitable (and, probably, they are already happening ${ }^{8}$ ). In order for legal scholarship to be able to preserve its doctrinal orientation, and to keep its practices continuous with its proud historical legacy, it must become more self-conscious about the potentials and limitations of doctrinal disciplinarity.

More clarity about the rationale and paradigms of interdisciplinary engagement can be helpful in exactly this respect. It is a good bet that interdisciplinary engagement will become ever more important for legal scholarship, and it will keep shaping the everyday practice of legal scholarship. Currently, the growing practice of interdisciplinary legal scholarship offers the best chance to break the culture of insularity that has been a feature of legal scholarship in many countries (and a damaging feature at that). Legal scholars are often guided by an intuitive sense that their scholarship is essentially different to the works of philosophers, social scientists, or other scholars. As I argue below, there is indeed something very specific about legal scholarship. But it is not and never has been a justification for a culture of insularity - for thinking that legal scholars can benefit little from other disciplines. In fact, the sense of the distinctiveness of legal scholarship can underlie a healthy disciplinary identity only if it is asserted, justified, and adequately articulated. Interdisciplinary engagement constitutes a discursive field where that might happen. In that sense, more interdisciplinary engagement actually strengthens the identity of legal scholarship as a doctrinal discipline. It is built into the very conceptual dynamics of interdisciplinary engagements that it brings into sharp relief the methodological integrity of participating disciplines. As it is engagement betmeen disciplines, ${ }^{9}$ it is premised on acknowledging ineradicable differences in disciplinary character and methodological profile.

I have mentioned above that I trace some features of legal scholarship to certain characteristics of law. In order to put the claims I make in that respect into perspective, it may be helpful to highlight here (before we start the more detailed analysis) that I operate with a couple of simplifying assumptions about law. I admit that they are open to contestation. But they are fitting for my characterisation of legal scholarship, and I regard them as defensible. First, the law is a normative and institutional social practice that seeks to guide behav-

8. Fiona Cownie has shown that British law schools are becoming more varied places than ever before - in terms of methodological credos and research practices. See F. Cownie, Legal Academics: Culture and Identities (2004). See also D.L. Rhode, 'Legal Scholarship', 115 Harvard Law Review 1327, at 1329 (2002).

9. Cf. D.W. Vick, 'Interdisciplinarity and the Discipline of Law', 31 Journal of Law and Society 163, at 188 (2004). iour. ${ }^{10}$ It does that primarily by authoritatively fixing norms (that can be formulated in terms of the rights and obligations of recognised agents). The law is implemented in procedures that facilitate argumentative engagement. Secondly, the law is open to deliberate changes. In fact, it has institutional procedures to bring about deliberate (even planned) modifications of its normative material. Those procedures attract extensive deliberation about institutional design. The ability to engage in debates on institutional design is an important aspect of advanced legal competence. These two assumptions have an implication that profoundly shapes my account of doctrinal scholarship: the legal practice generates fields (or arenas) of contestation. And it does that on two basic levels. The first is the contestation on the practical implications of the normative material. The law is open to interpretation: it accommodates differences of opinion and functions in the face of ineradicable disagreement. The second level is contestation on the ways in which the law could be changed for the better. Naturally, the two levels of contestation affect each other in many ways - creating dialectical tensions in the legal competence of lawyers, as well as legal scholars.

\section{The Character of Legal Doctrinal Scholarship}

As I have indicated above, my arguments are rooted in a particular conception of legal doctrinal scholarship. It confers on legal scholarship the function of cultivating doctrinal knowledge about law. As the point about legal scholarship and doctrinal knowledge is potentially the most controversial aspect of my theoretical position, I need to embed it in an epistemological clarification of doctrinal knowledge and anchor it in account of the practice of legal scholarship.

I do not think it is particularly difficult to provide an abstract account of the characteristic activities of doctrinal scholars. Most obviously, they engage with the current law. They develop and maintain a systemic perspective on existing normative materials and legal developments. ${ }^{11}$ Legal scholars work from conceptions on how the elements of the law fit together in their respective fields, and this qualifies them for assessing whether current developments can be reconciled with the given normative structures of law. The systemic perspective on the law also enables legal scholars to reorder and 'remap' the doctrinal structures of law when facing sweeping changes to legal materials (as a result of major legislative reforms or groundbreaking judicial decisions). It is similarly clear that legal scholars exercise a

10. See M. Bódig, 'The Issue of Normativity and the Methodological Implications of Interpretivism I: The Idea of Normative Guidance', 54 Acta Juridica Hungarica 119 (2013). Mátyás Bódig, 'The Issue of Normativity and the Methodological Implications of Interpretivism II: The Distinctive Normativity of Law', 54 Acta Juridica Hungarica 207 (2013).

11. See van Hoecke and Ost, above n. 2, at 197. Cf. N. MacCormick, Institutions of Law: An Essay in Legal Theory (2007), at 6. 
sort of quality control over judicial reasoning as it is manifested in upper court practice. ${ }^{12}$ Perhaps a bit less obviously, they also address contested matters on the exact normative scope of legal materials. ${ }^{13}$ These characteristic activities may cover most of what legal scholars do, but we should not forget that legal scholars also characteristically engage with issues of institutional design. It is not just that the assessment of the upsides and downsides of the existing law can culminate in reform proposals. Increasingly, contemporary legal scholarship is filling with policy content, and legal scholars often position themselves as experts on certain policy matters (energy policy, environmental policy, etc.). ${ }^{14}$ It is not that they claim doctrinal, as well as policy expertise. The two are intertwined because doctrinal plausibility is a vital factor in assessing the feasibility of policies in an institutional environment. Legal scholars may be the ones best qualified to figure out which policies (and by what legal strategies) can be written into law ${ }^{15}$ and also to figure out how the prospects of policies are affected by institutional decisions (like a court ruling).

I believe that these activities can be usefully understood as manifestations of the epistemological profile of a distinctive disciplinary perspective. They hint at the methodological characteristics of a normative and interpretive discipline that looks at legal practices from a strong internalist point of view. ${ }^{16}$ Let me explain briefly the constitutive elements of this claim.

Legal scholarship is explicitly normative (as opposed to having a hidden normative agenda - which is often the case with some sociological and anthropological research. It is not simply that legal scholarship deals with the normative aspects of a social practice. More importantly, it makes an explicit commitment to maintain the practice in its integrity and rationality. ${ }^{17} \mathrm{With}-$ out this, it could not take on the role of exercising quality control over judicial reasoning - it could not claim to offer an insider look on legal developments and chal-

12. See H.T. Edwards, 'The Growing Disjunction between Legal Education and the Legal Profession', 91 Michigan Law Review 34, at 43-5 (1992).

13. I see this in human rights law in particular. We have abundant literature on, say, whether transnational corporations have human rights responsibilities. The main benefit from such analyses is a better understanding of the scope of human rights obligations. See, e.g., A. Clapham, Human Rights Obligations of Non-State Actors (2006). D. Kinley and J. Tadaki, 'The Emergence of Human Rights Responsibilities for Corporations in International Law', 44 Virginia Journal of International Law 931 (2004). E. Engle, 'Extraterritorial Corporate Criminal Liability: A Remedy for Human Rights Violations?', 20 St. John's Journal of Legal Commentary 287 (2006).

14. For an example from a legal scholar, see A. Boute, 'Energy Efficiency as a New Paradigm of the European External Energy Policy: The Case of the EU-Russian Energy Dialogue', 65 Europe-Asia Studies 1021 (2013).

15. As we will see, this interplay between doctrinal expertise and policy issues is actually a major driver of interdisciplinary scholarship. I will say more about this interplay in section 4.

16. See S. Perry, 'Interpretation and Methodology in Legal Theory', in A. Marmor (ed.), Law and Interpretation: Essays in Legal Philosophy (1995) 97, at 98

17. Cf. Peter Birks, 'The Academic and the Practitioner', 18 Legal Studies 397, at 401 (1998). See also MacCormick, above n. 11, at 6. lenges. ${ }^{18}$ It is this 'insider perspective' that I point to when characterising legal scholarship as internalist. Actually, one of the key features of legal scholarship is the way its normative character and internalism come to be closely intertwined..$^{19}$ Legal scholarship does not simply engage with given institutional practices: it internalises their value assumptions. More specifically, a valueladen assumption about legal practices is constitutive of the perspective of legal scholarship: it is an improvement on the normative structures of social life and the institutional procedures of governance that they are permeated by legal norms. ${ }^{20}$ The authority manifested in the legal materials commands (and warrants) respect. Or, to put it in more abstract terms, 'legality' (that is, the ideal of the 'rule of law' as manifested in legal practices) is an attractive value with great social and political importance. $^{21}$

We can also glean from the characteristic activities of legal scholars that legal scholarship is interpretive in character. It means, first of all, that legal scholarship always remains practice specific. ${ }^{22}$ Legal scholarship construes the normative materials as positive law - as opposed to a repository of abstract political or moral principles that have independent normative force regardless of acts of enactment. An understanding of the normative implications of the practice, the competence criteria for participation, and the feasible ways of improving the given practice all develop from interpretive engagements with the positive law. Uniquely among disciplines, legal scholarship does not treat the law as the mere object of scholarly reflection: the normative content of the law also provides the conceptual framework that one must rely on to make sense of the legal practice. ${ }^{23}$ In fact, without an epistemologically

18. An important implication of this is that legal scholarship has a conservative streak to it. It does not mean that legal scholarship cannot embody bold imagination on matters of institutional design or that it cannot be fiercely critical of legal developments. But it means that its potential radicalism is tempered by the need to remain a manifestation of an insider perspective on the given legal practice. I will say more about legal scholarship and institutional design in section 4.

19. Cf. C. McCrudden, 'Legal Research and the Social Sciences', 122 Law Quarterly Review 632, at 633 (2006)

20. It has to be noted, even though it will not be at the centre of my analysis, that the unquestioning acceptance of legality as a value (and the explicit commitment to improving the legal practice) confers an ideological character on legal scholarship. There is no running away from this. We should not forget that it is not that legal scholars happen to end up advocating the value of legality (like an anthropologist may become sympathetic to the cultural values she comes into contact with). The commitment to the ideal of the rule of law is an internal even constitutive feature. From within the perspective of legal scholarship, it cannot be questioned. It is an ideological commitment. Note that, for Mark Tushnet, this is the reason why legal scholarship can never be a real science. See, e.g. Tushnet, above n. 2, at 1222

21. See, e.g. Ronald Dworkin, Justice in Robes (2006), at 5. D. Sugarman, 'Legal Theory, the Common Law Mind and the Making of the Textbook Tradition', in William Twining (ed.), Legal Theory and Common Law (1986), at 27

22. Cf. E.J. Weinrib, 'Can Law Survive Legal Education?', 60 Vanderbilt Law Review 401, at 404 (2007). Dworkin (2006), above n. 21, at 2.

23. I rely here on a brilliant insight by Pauline Westerman. See P. Westerman, 'Open or Autonomous? The Debate on Legal Methodology as a Reflection of the Debate on Law', in Mark van Hoecke (ed.), Methodologies of Legal Research (2011), at 90-4. 
plausible idea of 'positive law', we could not even make sense of legal scholarship. All epistemic gains legal scholarship offers are premised on knowing what the law is. At the end of the day, its epistemic gains are meaningful only for those who know the law or want to know the law as it has been laid down by authorities.

I note that the way interpretivism plays out in legal scholarship is crucial to understanding its distinctive character. Interpretive engagement with normative materials is common in other disciplines as well - most obviously in history. Interpretive engagement combined with explicit practical concerns can also be characteristic of applied ethics (e.g. bioethics ${ }^{24}$ ). The distinctive feature is that the interpretivism of legal scholarship revolves around the authority attributed to canonical normative texts (i.e. positive law). In this respect, the only other discipline on par with legal scholarship in terms of its methodological features is theology (when it attributes the authority of the 'sacred' to certain texts).

Perhaps, we can make these points clearer by drawing a few more explicit contrasts with other disciplines. Legal scholarship is unlike political and moral philosophy: the latter is explicitly normative but not practice specific and interpretive in their truth claims. Much of the practice of the social sciences is interpretive (e.g. social anthropology), but, unlike legal scholarship, it is not explicitly normative. Some disciplinary perspectives are normative and offer ways of interpreting the normative material but still remain characteristically different from legal scholarship. For example, the economic analysis of law (that has the methodological profile of economics) has a normative agenda, but it is imposed on law - not revealed from it by way of interpretive engagement with positive law. It interprets the law from a fundamentally extralegal normative perspective. As a result, it offers a thoroughly instrumental perspective on law that sits uneasily with the epistemological profile of legal doctrinal scholarship..$^{25}$

\section{Doctrinal Knowledge and Doctrinal Scholarship}

Of course, this is still not enough as an account of the character of legal scholarship. We still miss something essential if we remain on the level of a formal characterisation of a normative and interpretive discipline. We need to see the distinctive a point to building an academic discipline that takes this interpretive and normative approach to legal practices. As I have indicated, my way of making sense of these characteristics is to say that legal scholarship has the function of cultivating

24. See, e.g., H.T. Engelhardt, The Foundations of Bioethics (2nd ed., 1996).

25. I believe that Ernest Weinrib was right on the point in his 'crusade' against the growing influence of the Economic Analysis of Law. See, e.g., Weinrib, above n. 22, at 406-14 doctrinal knowledge. ${ }^{26}$ Without asking a few questions about doctrinal knowledge, my account of legal scholarship would remain partly unintelligible.

In my understanding, doctrinal knowledge grows in and around normative social practices (like the different incarnations of law or religious practices), and it is specifically focused on their normative aspects. Mastering doctrinal knowledge presupposes the familiarity with the norms of the given practice ('knowing what the rules are'), but this is not what determines its character. Doctrinal knowledge builds competence about the justificatory implications of the normative terms of participation. In principle, one can recite each norm of the practice and can still be incompetent in this specific sense. Gaining doctrinal knowledge enables one to align one's actions and practical judgments with the normative content of the given practice - to get clear on what it takes to act and reason without subverting its integrity. It helps figure out how far one can go without falling foul of the normative terms of participation. In other words, it is knowledge fit into the normative parameters for social practices. Importantly, it means the doctrinal knowledge 'internalises' the viewpoint of the committed participants of the practice. Doctrinal knowledge is premised on the acceptance of normative guidance from the relevant practice. Doctrinal knowledge is particularly important for those who seek to gain competence in navigating fields of contestation within normative practices. Doctrinal knowledge enables them to figure out what is compatible with fidelity to the given practice what can be done and said without running the risk of becoming an outsider.

A crucial implication of all this is that what mastering doctrinal knowledge facilitates is not improved compliance (and definitely not blind obedience) but the ability to negotiate one's options in a normatively constructed social environment. ${ }^{27}$ In other words, doctrinal knowledge thrives on contestation. In fact, doctrinal knowledge comes into its own when the normative assessment of situations is opened up for contestation within the practice itself - that is, when the complexity of the practice leaves room for significant interpretative disagreement. ${ }^{28}$ At first glance, this point may seem to be in tension with the commitment to maintaining the given practice in its integrity (that I have emphasised above). But it is actually the shared commitment that makes intense contestation among the participants possible

26. As I work from a more abstract epistemological paradigm, I could not rely on a 'legal doctrine' or the 'legal doctrine' as my basic conceptual building block, even though they might have looked more familiar (even plausible) for legal scholars.

27. Compliance is often a matter of basic social skills that do not require the development of any specialised knowledge. Compliance is often and repeat compliance is typically habitualised.

28. There is a further condition that I do not go into here. Contestation can only shape the practice if normative disagreements are not suppressed by unfavourable power dynamics. This concerns the sociological conditions under which doctrinal knowledge can unfold and can influence social practices. 
without the disintegration of the given practice. ${ }^{29}$ It is more accurate to say that doctrinal knowledge thrives on contestation that remains internal to particular normative practices.

A further implication of this inherent connection with contestation is that doctrinal knowledge is premised on taking a perspective on social practices that makes them appear as dynamic and contingent constructions continuously shaped by human efforts - by what participants do about them and think of them. Doctrinal knowledge, by generating an awareness of interpretive variability, internal tensions, and patterns of contestation, facilitates 'active agency' 30 both among the addressees of the norms of the given practice and, in the case of formally institutionalised practices, the officials. Within the bounds of fidelity to the given practices, doctrinal knowledge brings about creative engagement with practice-related normative materials.

Crucially for my analysis, these observations suggest that the character-defining features of legal scholarship (that I have listed in the precious section) are actually rooted in the epistemological profile of doctrinal knowledge. ${ }^{31}$ (1) Doctrinal knowledge is practice oriented: it is born out of engagement with the normative aspects of social practices. (2) Doctrinal knowledge perceives practices as contingent, man-made, and subject to change. It understands social practices as inherently precarious: they would not survive without the commitment and contribution of its participants. (3) Doctrinal knowledge is practice specific and interpretative: it takes an internal point of view to actual, historically contingent practices and is limited to those practices in its truth claims. (4) Doctrinal knowledge is normative and not simply because its objects are norms and their justificatory implications but mainly because it is adjusted to a practical orientation: accepting normative guidance from the given practice ${ }^{32}$ and being committed to maintaining it in its integrity. (5) And, finally, doctrinal knowledge is noninstrumental about the practice it is related to.

29. I believe that this is one way to make sense of Dworkin's claim that the law is an 'argumentative practice'. Cf., e.g., R. Dworkin, Law's Empire (1986), at 13-4

30. Many have realised that the law operates by using, as opposed to suppressing, the agency of humans. For a recent formulation of the point, see J. Waldron, 'The Concept and the Rule of Law', 43 Georgia Law Review 1, at 26 (2008). I tie this feature to the doctrinal character of law.

31. This close connection between doctrinal knowledge and doctrinal scholarship makes the functional connection between the legal profession and legal scholarship rather obvious. Legal doctrinal scholarship exists in a constitutive relationship with the legal profession (paradigmatically manifested in its role in legal education). This is widely acknowledged by scholars who reflect on the character of legal scholarship - although they are very much divided on whether they should welcome its implications. See, e.g., C. Tomlins, 'Framing the Field of Law's Disciplinary Encounters: A Historical Narrative', 34 Law and Society Review 911, at 925 (2000). Vick, above n. 9, at 175. S. Taekema, 'Relative Autonomy: A Characterisation of the Discipline of Law', in B. van Klink and S. Taekema (eds.), Law and Method: Interdisciplinary Research into Law (2011). As I have indicated above, I leave on one side the rich implications of this point.

32. For my account of normative guidance, see Bódig (2013), above n. 10, at $124-30$.
Due to its special significance, we need to say more about this final point on noninstrumentalism. I have claimed that doctrinal knowledge answers to the epistemic needs of those who accept normative guidance from the practice. This is the point that needs some elaboration to get a grip on the noninstrumentalist character of both doctrinal knowledge and legal scholarship. In the sense relevant for us here, accepting normative guidance does not simply mean that one factors in the norms of a social practice in practical deliberations. It is actually a manifestation of a specific mode of participation. Engaging with the practice is never simply about how to use its normative materials and institutional structures to one's subjective ends. Doctrinal knowledge is generated in the process of not simply learning about the practice but also learning from the practice. Its epistemic merits are conditional on accepting that the practice has a value content that one can access only through participation ${ }^{33}$ and that the practice engages with what a committed participant can regard as appropriate practical objectives and the appropriate ways of pursuing them. In that sense, one of the very functions of doctrinal knowledge is to shape one's perspective on social life - one's moral and political outlook. ${ }^{34}$

The way doctrinal knowledge takes on a noninstrumental character helps us understand better the close connection between the internalist (practice related and practice oriented) and interpretivist features of doctrinal knowledge, as well as doctrinal scholarship. The mere challenge of making sense of social practices by way of interpretive engagement with their normative materials does not make it necessary that one takes a strong internal point of view to them. ${ }^{35}$ It becomes necessary only in light of the commitment to maintaining the given practice in its integrity. And the epistemological justification for that commitment lies in the conviction that a noninstrumentalist perspective on the given practice promises specific epistemic gains. It is this promise of specific epistemic gains (on values with major social significance) that underlies the disciplinary character of legal scholarship. This is how it can offer knowledge that other disciplinary perspectives do not have access to.

33. This claim is inspired by Maclntyre account of 'internal goods'. See A. Maclntyre, After Virtue (2nd ed., 1984), at 190-1.

34. It is for this reason that I insist on the somewhat counterintuitive claim that, even though its elements can be employed instrumentally, the character of doctrinal knowledge does not fit an instrumentalist model. One can borrow doctrinal knowledge (on what can and cannot be done without falling foul of the norms of the given practice) with manipulative or simply self-serving intentions. One may fake the commitment implied in the idea of participation, and one may use strategically some piece of intimate practice-related knowledge to plot one's way around the given practice. But it means consciously giving up on one of the epistemic gains that define the character of doctrinal knowledge (the capacity to shape one's outlook on social life). In fact, it is very difficult to provide an adequate explanation for the very emergence of doctrinal knowledge from a purely instrumentalist perspective. No known body of doctrinal knowledge could have developed without commitment to maintaining the underlying social practices in their integrity.

35. Cf. Perry, above n. 16, at 123, G. Postema, 'Jurisprudence as Practical Philosophy', 4 Legal Theory 329, at 341 and 350 (1998). 


\section{The Paradigms of Interdisciplinary Engagement}

It is time to test whether these considerations about doctrinal knowledge and the character of legal scholarship will help us understand better why and how interdisciplinary engagement makes sense for legal scholars. Above, I distinguished between two aspects of the practice of legal scholarship: dealing with the existing legal materials and engagement with challenges of institutional design. The two remain analytically distinguishable, but they interact with each other in important ways. It seems to me that legal scholarship of any notable quality is very much characterised by the shuffling between the multifarious analysis of given normative materials and addressing issues of institutional design. Engaging with institutional design facilitates creative approaches to the systemic aspects of existing law. It brings home the point that the normative elements of law are (to a varying extent) contingent. And the challenge of reforming the law again and again raises stark questions for legal scholarship about the ways of protecting the integrity, coherence, and rationality of the law. Also, the concern with institutional design brings into focus the complicated relationship between the normative implications of the existing law and considerations of public policy. If we want to understand the problem of interdisciplinary engagement in legal scholarship better, we need to be able to associate its manifestations to these two aspects of the practice of legal scholarship.

I have indicated above that I do not set out to provide a complete theory of interdisciplinary interaction for legal scholarship. Instead, I identify a few paradigms of interdisciplinary engagement for legal scholarship in order to explore the implications of my account of doctrinal scholarship and doctrinal knowledge. Nor do I go into analysing the exact typology of interdisciplinary methods that legal scholars may apply. Taekema and van Klink have already offered a useful analysis of interdisciplinary methods that I do not wish to second guess here. ${ }^{36} \mathrm{I}$ hope that my analysis will remain largely compatible with theirs, and I can shift the focus to what makes interdisciplinary engagement necessary (and beneficial for legal scholarship) in certain contexts.

I have also pointed out above that, even though interdisciplinary engagement in legal scholarship has broad methodological varieties, it still has a distinctive rationale (that is due to certain features of law). It is important to elaborate on this point before we turn to the paradigms of interdisciplinary engagement. It will help us understand better what links the three paradigms I address and what distinguishes them.

As to the distinctive rationale of interdisciplinary engagement, it needs to be linked to the very function of legal scholarship: cultivating doctrinal knowledge. What

36. S. Taekema and B. van Klink, 'On the Border: Limits and Possibilities of Interdisciplinary Research', in B. van Klink and S. Taekema (eds.), Law and Method: Interdisciplinary Research into Law (2011). we need to keep in mind is that the challenge of cultivating doctrinal knowledge about law is complicated by the fact that the law operates with concepts and principles that cannot always be made fully intelligible through normative analysis that remains internal to given legal practices. There is a constant flow of extra-legal information into legal procedures and practice-related policy debates that has a pervasive impact on how the normative materials of law turn out. The law is not just a system of action-guiding norms but a framework for deliberation and public justification as well, ${ }^{37}$ and, even when it develops artificial categories (like 'legal causation' and 'remoteness of damage'), the justifications it provides for practical judgements must remain intelligible for its addressees. The law has its own internal value structures, but they interact with a large amount of extralegal information. As a result, doctrinal knowledge exists in a state of permanent renewal, and legal scholarship cannot claim exclusive semantic competence to define the categories it operates with (the way some formal sciences like mathematics can). In an important sense, the law is constituted as a 'parasitic discipline'. ${ }^{38}$ And, of course, it means that interdisciplinary engagement becomes a vital aspect of maintaining and improving the ability of legal scholarship to cultivate doctrinal knowledge.

If this is true, the paradigms of interdisciplinary engagement must all be related to the various challenges that the flow of extralegal information into the law poses. This is what is reflected in the 'paradigms' I address below. The first concerns gaining some interpretive depth on the concepts and ideas deposited in law. The second concerns situations where legal scholarship comes into potential conflict with alternative disciplinary perspectives. And the third concerns the pressure of extra-legal considerations for altering the law.

\subsection{Understanding Extralegal Origins}

In a sense, the first paradigm of interdisciplinary engagement is the most straightforward. It can be traced back to a direct implication of a point I have made above on the limited 'epistemic' reach of legal scholarship: the conceptual elements of the current law cannot always be made fully intelligible from an internal perspective. The conceptual elements doctrinal structures are built from typically have some historical depth (they did not always mean what they mean now), and they often reflect the impact of political controversies and compromises. Legislation and adjudication are prone to be influenced by

37. Cf. G. Postema, 'Law's Autonomy and Public Practical Reason,' in R.P. George (ed.), The Autonomy of Law: Essays on Legal Positivism (1996) 79 , at 112 .

38. See A. Bradney, 'Law as a Parasitic Discipline', 25 Journal of Law and Society 71 (1998). 
broader political, social, and intellectual trends. ${ }^{39}$ Ignorance about this pedigree of the normative materials of law can make legal scholarship positively implausible. It can make the interpretive engagement with the positive law (which is the bread and butter of legal scholarship) shallow and erratic. It is no surprise that all legal scholars demonstrate some understanding of the historical depth of legal concepts - e.g. of the political philosophical categories that found their way to their doctrinal arsenal (like the 'separation of powers', 'sovereignty', or 'democracy'). This indicates how the interpretive character of legal scholarship can stimulate interdisciplinary engagement.

Of course, merely acknowledging the impact of social and political realities on the content of law does not necessarily imply the need for genuine interdisciplinary engagement. Most importantly, it does not necessarily require legal scholars to build competence in other disciplines. This may come about when there is some specific doctrinal stake in gaining more clarity about the extra-legal disciplinary roots of important legal categories. An example for this may be the engagement with philosophical problems of corrective justice in tort scholarship a few decades ago. ${ }^{40}$ It meant taking a far deeper look at philosophical issues than mere doctrinal reflection could ever warrant: it indeed meant significant interdisciplinary engagement. The main reason for this phenomenon was that the emergence of the economic analysis of law made raised the stakes of debates on tort law doctrines and generated controversies about the very point of tort law. For those who resisted the reconstitution of tort law along the lines of an essentially consequentialist project, digging down to the (Aristotelian) philosophical origins of traditional tort law doctrine offered the promise of more interpretive and theoretical depth in their doctrinal positions. In a sense, the motivation for interdisciplinary engagement was not just interpretivism but the felt need to preserve the noninstrumentalist perspective of legal scholarship.

Even though it has very significant potential to influence doctrinal debates, and it raises its own methodological challenges (legal scholars may have difficulties with guaranteeing that they do not misunderstand the alter-

39. I have in mind the well-documented trend shift in the United States in the New Deal era. Before the New Deal, Supreme Court jurisprudence was characterised by a rigid and formalistic emphasis on individual freedom. Infamous decisions like Lochner v. New York (1905) 198 US 45 were manifestations of this trend. The New Deal brought about a major shift that ultimately generated the judicial activism of the Warren court in the 1950s - with its more substantive approach to civil rights (and the equal protection clause of the Constitution in particular). See N. Duxbury, Patterns of American Jurisprudence (1995). American legal scholars are all aware of this impact of broader social and political trends (and they factor it in when dealing with precedents from different periods), but, in the context of academic writing, they could not verify their assumptions about them without resorting to other disciplinary perspectives.

40. See, e.g., E. Weinrib, 'Toward a Moral Theory of Negligence Law', 2 Law and Philosophy 37 (1983). C.P. Wells, 'Tort Law as Corrective Justice', 88 Michigan Law Review 2348 (1990). C.H. Schroeder, 'Corrective Justice, Liability for Risks, and Tort Law', 38 UCLA Law Review 143 (1990). J.L. Coleman, 'Tort Law and the Demands of Corrective Justice', 67 Indiana Law Journal 349 (1992). native disciplinary perspectives), I still maintain that this is the least interesting paradigm of interdisciplinarity in law. This paradigm has been present in legal scholarship from effectively the beginning, and its focus on understanding better what is already in the law makes it an unlikely candidate for being a major driver of either doctrinal development in the law or the methodological renewal of legal scholarship. It seems to me that the other two paradigms I address here have a more direct bearing on the pressing methodological challenges of contemporary legal scholarship.

\subsection{Addressing Frictions between Disciplinary Perspectives}

As I have indicated, the second paradigm concerns situations where legal scholarship comes into potential conflict with alternative disciplinary perspectives. As we have seen, the first paradigm revolves around acknowledging the limitations of legal scholarship in making adequate sense of ideas and concepts that came to be integrated into legal materials. It assumes a fundamentally supportive relationship between legal scholarship and the relevant other disciplines. One discipline can lend more interpretive depth to the other. There are cases, however, when the engagement between disciplines is characterised more by rivalry and even tension. There are categories that are crucial for legal scholarship for their doctrinal significance but other disciplines also have significant stakes in them. Nothing guarantees that the different disciplinary perspectives on them will not end up at least partly incompatible. In many cases, this raises no serious challenge because the alternative uses of the affected concepts can be contextually separated. (We can learn to appreciate that 'fault' or 'acceptance' means something different in law than elsewhere.) Occasionally, however, the engagement simply cannot be avoided, and it can even become strategically important for legal scholarship to maintain some control over the semantic boundaries of the relevant categories. The internal coherence of the doctrinal structures may depend on it. Communication and some form of accommodation are unavoidable.

I think I can best explain the challenges that the second paradigm addresses through a concrete example: the challenges facing causation jurisprudence in the law of delict. ${ }^{41}$ There are aspects to the doctrinal approach to causation issues that are internalised by legal scholarship but make little sense for other disciplines. Most importantly, for lawyers and legal scholars, issues of causation are never simply a matter of factual relations: they remain intertwined with issues of the scope of liability. ${ }^{42}$ This is bound to cause some friction with scientific accounts of causal connections that treat causation as a

41. I rely here on an earlier analysis of mine. See Bódig (2013), above n. 7.

42. 'The causal requirements for liability often vary, sometimes quite subtly, from case to case. And since the causal requirements for liability are always a matter of law, these variations represent legal differences...', Fairchild v. Glenhaven Funeral Services (2003) 1 AC 32, at 72, per Lord Hoffmann. See also T. Honoré, Responsibility and Fault (1999), at 4-5 and $100-1$. 
straightforward factual problem and that keep influencing legal decisions through the contribution of forensic experts in court procedures. These frictions cannot be addressed by simply giving priority to one disciplinary perspective over the other. The non-instrumental perspective of legal scholarship would be an insurmountable obstacle to that. They can only be handled through a productive engagement with the alternative disciplinary perspectives. Inevitably, the terms under which doctrines of causation can remain fully intelligible and practicable will at least partly be dictated by forensic expertise. $^{43}$

We should be a bit clearer about the dynamics of this pressure on causation jurisprudence. Its root is the realisation that lawyers and legal scholars simply cannot ignore the relevant scientific knowledge (or openly contradict scientific evidence) when addressing causation issues. They are not well positioned to insist that a causal connection is there when they say it is - that they can develop a self-standing, specifically 'legal-doctrinal' sense of causation. ${ }^{44}$ Simply ignoring what sciences (like medicine) figure out about causal relations (e.g. on the causes of a disease) would look downright irrational. It would raise very serious legitimacy issues about the epistemic authority and academic credibility of legal scholars. ${ }^{45}$ What legal scholars need to achieve is an acute understanding of how the insights of forensic science can be accommodated without subverting the doctrinal structures of causation jurisprudence. It means building competence in forensic science, and it has produced some important pieces of interdisciplinary legal scholarship. ${ }^{46}$ Some say that, at least in the context of the legal procedure, this has resulted in the mutual erosion of a stark contrast between the legal and the scientific approach to causation (without erasing the salient differences). ${ }^{47}$ I would prefer to talk of an ongoing learning process that has never lost its original focus on doctrinal integrity. It meant opening up causation doctrines to scientific developments but maintaining the lawyers' claim to superior interpretative competence in determining which accounts of causal relations are preferable when dealing with issues of liability.

43. It is worth emphasising that I do not claim that the progress of forensic knowledge is the only driver of doctrinal development. Other considerations often play a decisive role. But it is one important factor.

44. No doubt, it was sometimes tempting to cut through the complications by acknowledging that lawyers are free to mean by causation whatever they see fit. 'For lawyers, just as 'duty' and 'damage' mean what we decide they should mean in a legal context, so it should be with the concept of causation'. M. Hogg, 'Developing Causal Doctrine', in R. Goldberg (ed.), Perspectives on Causation (2011), at 44. But this approach never came to dominate causation jurisprudence.

45. See G. Edmond and D. Mercer, 'Rebels without a Cause? Judges, Medical and Scientific Evidence and the Uses of Causation', in I. Freckleton and D. Mendelson (eds.), Causation in Law and Medicine (2002), at 86-7.

46. See R. Goldberg, Causation and Risk in the Law of Torts: Scientific Evidence and Medicinal Product Liability (1999).

47. Cf P. Greenberg, 'The Cause of Disease and Illness: Medical Views and Uncertainties', in I. Freckleton and D. Mendelson (eds.), Causation in Law and Medicine (2002), at 53.
As we see, in this context, interdisciplinary engagement means taking on a constant methodological challenge that comes to drive the development of doctrinal knowledge. In relation to causation issues, it has encouraged theoretical sophistication to a previously unknown extent. $^{48}$ It has brought into focus exciting questions about the interplay of normative and factual considerations. ${ }^{49}$ On the other hand, I cannot help thinking that this paradigm of interdisciplinary engagement still has not fulfilled its potential for informing and shaping the broader practice of legal scholarship. Its impact is largely local: it generated 'pockets' of a more interdisciplinary minded discourse in legal scholarship. This is regrettable because the 'skirmishes' between different disciplinary perspectives have systemic significance for legal scholarship. Perhaps, this is where legal theory could do more to draw the epistemological and methodological lessons from the way discursive mismatches between disciplinary perspectives come to reflect the epistemological character of legal scholarship. ${ }^{50}$

\subsection{Doctrinal Knowledge, Policy Initiatives, and Institutional Design}

Let me turn now to a third paradigm of interdisciplinary engagement. I have mentioned at the beginning of this section that we can distinguish between two aspects of the practice of legal scholarship: dealing with the existing legal materials and engaging with challenges of institutional design. The two intersect in complex ways, but the analytical distinction remains a sound one - determinative of the character of legal scholarship. I believe that the distinction has a bearing on the paradigms of interdisciplinary engagement. It seems to me that the first and second paradigms are more closely related to handling normative materials. With the third one, we shift the focus to issues of institutional design. The third paradigm is more closely related to a point that I have also highlighted above: for contemporary legal scholarship, issues of institutional design arise in an intellectual and political environment in which a flood of policy initiatives keep the law under constant pressure. ${ }^{51}$ In that environment, competence in policy matters plays an increasingly important role in preserving

48. In this respect, in the English language literature, Jane Stapleton and Richard Wright stand out among the doctrinal writers. See J. Stapleton, 'Scientific and Legal Approaches to Causation', in I. Freckleton and D. Mendelson (eds.), Causation in Law and Medicine (2002). J. Stapleton, 'Cause-in-Fact and the Scope of Liability for Consequences', 119 Law Quarterly Review 388 (2003). R. Wright, 'Causation in Tort Law', 73 California Law Review 1735 (1985). R. Wright, 'Causation, Responsibility, Risk, Probability, Naked Statistics and Proof: Pruning the Bramble Bush by Clarifying the Concepts', 73 lowa Law Review 1001 (1988). R. Wright, 'Proving Causation: Probability versus Belief', in R. Goldberg (ed.), Perspectives on Causation (2011).

49. See Bódig (2013), above n. 7.

50. That is the issue that was at the heart of my earlier analysis in Bódig (2010), above n. 7

51. I see this as a natural consequence of the way modern political systems work: a broad range of agents have the (often slight) opportunity to influence the way the polity is governed. But lasting impact on governance is only possible if the initiatives are consolidated as legal measures. Attempts to influence the practice of governance are bound to take the form of policy proposals to amend the law. 
the influence of legal scholarship over debates on institutional design. The third paradigm of interdisciplinary engagement I address is an aspect of handling this challenge.

It is important to emphasise that the way this pressure affects legal scholarship reflects a particular feature of the disciplinary character of law. The pressure is not really generated by policy preferences internal to legal scholarship clashing with policy initiatives arising from extra-legal social and political processes. Legal scholarship is thin in policy content. Even though its concern with maintaining the integrity, coherence, and rationality of doctrinal structures has some direct policy implications, ${ }^{52}$ legal scholarship exhibits remarkable openness and flexibility when it comes to absorbing policy preferences. For a discipline that takes an internalist and interpretivist perspective on normative materials (and that, by implication, is premised on deference to what is already built into the normative structures of law), internal intellectual resources can hardly generate a forceful policy agenda. The internal value structures law (and the ideal of the rule of law in particular) do not embody blueprints for comprehensive purposive arrangements of human relations. It is no surprise then that the tools of doctrinal reasoning legal scholars master can be used to support a broad variety of different policy initiatives (often in direct conflict with each other). A crucial implication of this is that, contrary to what one might think, legal scholarship has very limited potential when it comes to generating independent visions of institutional design. ${ }^{53}$ The potential does not extend far beyond addressing internal dysfunctions that doctrinal analysis often uncovers. ${ }^{54}$ The pressure from ambitious policy initiatives to alter or restructure the law tends to come from outside legal scholarship.

Under these circumstances, it becomes a challenge for legal scholarship to make judgements on the merits of policy initiatives. ${ }^{55} \mathrm{We}$ know that policies cannot be accommodated in the legal materials without some doc-

52. This is mainly because the rationality of legal materials can be a hotly contested matter itself.

53. Legal scholars, of course, can be vigorous advocates of law reform. What I claim is that their preferences for the desired changes in the content of law or its institutional structures cannot be explained from considerations internal to doctrinal knowledge. They reflect political choices that go well beyond the concern with cultivating doctrinal knowledge.

54. In Britain, this typically takes the form of pointing out some glaring flaw in the way the case law has developed in a particular area. Here is a paradigmatic example: 'The law on recovery in negligence for psychi atric injury where the pursuer has not suffered any physical injury but has witnessed the death or injury of another has been described as "confusing and arbitrary", a "panoply of artificial rules", "irrational and unsympathetic", and "the area where the silliest rules now exist and where criticism is almost universal". In fact, it is difficult to think of another branch of delict that has been subject to such extensive condemnation.' F. Leverick, 'Counting the Ways of Becoming a Primary Victim: Anderson v. Christian Salvesen PIc', 11 Edinburgh Law Review 258 (2007).

55. I elaborate on a point here that I developed elsewhere. See M. Bódig, 'Doctrinal Knowledge, Legal Doctrinal Scholarship and the Problem of Interdisciplinary Engagement', in S. van Praagh and H. Dedek (eds.), Stateless Law?: Evolving Boundaries of a Discipline (2015). trinal 'encoding'. This makes legal scholars crucial agents in the (essentially political) discourse on how changes to the law can be implemented without systemlevel dysfunctions. But, of course, before addressing the issue of what the best ways of implementing those policies are, legal scholars need to make a judgement on which policies are worth the effort of doctrinal encoding. Exactly because of its propensity to absorb policy considerations, the doctrinal analysis legal scholars resort to has precious few internal resources to support the judgement on the merits of policy initiatives. In this respect, once again, the essential internalism of the doctrinal perspective comes with severe methodological limitations. Wasting efforts on figuring out doctrinal models for policy initiatives that are not worth it can make legal scholars look misguided and hopelessly out of touch.

This is where interdisciplinary scholarship offers pretty much the only feasible way to preserve the competence of legal scholarship in exercising some control over doctrinal development. Legal scholars cannot rely on a raw political logic in taking a stand on the demands to make changes to the law - without running the risk of looking cynical. As an academic discipline, legal scholarship needs academic validation for the substantive ideas that it chooses to embed in the doctrinal structure of the existing law. Only other disciplines can vouch for the claim that, say, 'indirect discrimination' is a genuine problem that calls for new regulation, ${ }^{56}$ that a crisis of democracy makes the overhaul of the constitutional mechanisms of popular representation necessary, or that we need more imaginative normative tools to address the human rights aspects of environmental harm. What these examples suggest is that assessing the worth of policy initiatives has at least three dimensions - each of them outside the remit of doctrinal analysis properly socalled. The first is conceptual clarity: are ideas like 'welfare dependency' clear enough to lend itself to practicable solutions by government action in the first place? The second concerns the plausibility of factual assumptions: are there people in significant numbers who can be described as 'welfare dependant'? The third dimension concerns normative plausibility (i.e. the fit with accepted political and moral values): is proportional representation fairer or a better fit for the democratic ideal than the 'first past the post' system of electing the members of parliament?

Importantly for us, this does not simply mean that legal scholarship must pass certain issues on to other disciplines. The judgement on the worth of policy initiatives cannot be simply outsourced. We are talking about judgements of feasibility that put the professional credibility of legal scholars on the line. That is why they need to build competence by way of interdisciplinary engagement. They need to be able to find their way around the

56. Initially, UK anti-discrimination law only addressed what we now call 'direct discrimination'. Prohibiting indirect discrimination as well was one of the pivotal doctrinal developments in this area, and it happened when Sex Discrimination Act of 1975 was enacted. 
disciplines related to their own fields of law (be it ecology, political sociology, or economics). Otherwise, as I have pointed out, they risk losing some of their influence over the way the law will change.

As I have mentioned above, it is indeed more and more typical that contemporary legal scholars build competence in other disciplines along these lines. Many of them see themselves experts for the academic validation of policy preferences, as well as experts of doctrinal analysis. I believe that this is an implication of an interesting (and insufficiently analysed) shift in contemporary disciplinary practice. We witness the growing significance of interdisciplinary fields of study (on migration, international conflicts, sustainable development, climate change policy, energy, etc). Legal scholars gravitate towards these fields (not least because of the attractive opportunities for research funding), and combining doctrinal and policy expertise makes it much easier to establish themselves in any one of them. ${ }^{57}$

The third paradigm of interdisciplinary engagement may well be the most significant from a methodological point of view - the most revealing about the character of doctrinal knowledge, of legal scholarship, and of the way doctrinal disciplinarity fits into the broader academic environment. The shuffling between doctrinal analysis and the elucidation of the background to policy challenges is rich in implications for the ways knowledge from different disciplines (doctrinal and non-doctrinal) can be reconciled with each other. Focusing on the third paradigm might offer the best vantage point to understanding the strategic importance of getting the terms of interdisciplinary engagement right in legal scholarship. It also helps us understand that there is no inherent tension between the concerns of legal scholarship and policy-driven approaches to practical challenges. And it certainly does not make it plausible to think that the law is a mere institutional tool for implementing policies.

Even though this pattern of interdisciplinary engagement can have a pervasive impact on the agendas for individual legal scholars, the increased concern with policy challenges (that animates the third paradigm) does not obscure the distinctive character of legal scholarship. Even in the context of intense interdisciplinary communication, the primary focus for legal scholarship remains markedly different from other disciplines. When it comes to questions about the ways in which the changing social environment and the shifting commitments to political values interact with the normative functioning of legal institutions, we might be concerned with two clearly different sets of considerations. We can be interested in how the law affects its social environment and whether it offers a viable opportunity to institutionalise important political ideals. Or, alternatively, we can be concerned with the ways in which the changing social and political environment affects the conditions of maintaining the doctrinal coherence of the nor-

57. [In contemporary universities, we see the emergence of] interdisciplinary research centres that are welcoming for legal scholars (e.g....). Narrow doctrinal focus, however, is not rewarded. mative elements of law. That is, we might want to know the consequences for the law of the shifting patterns of knowledge about social and political relations, ideals and attitudes, as well as institutional realities. Legal scholarship (due to its noninstrumentalist take on law) stands alone among the disciplines with its obvious focus on the latter point. Without its contribution, the question of how the social environment affects the law (as opposed to how the law affects the social environment) and what can and cannot be done without undermining the doctrinal structures of law would be left without adequate academic reflection.

It is also important to point out that my characterisation of the third paradigm is designed to draw a marked contrast to an alternative model of interdisciplinary engagement that has proved enduringly attractive among legal scholars. This alternative model would derive the opposite conclusion from the inherently plausible idea that legal scholarship needs to engage more with the social and political environment in which the law operates. It concludes that legal scholarship must learn more about the social consequences of operating the characteristic legal mechanisms. Memorably, American legal realists often argued along these lines, ${ }^{58}$ and Richard Posner also formulated a similar position when assessing how legal theory and legal scholarship could be helpful for legal practitioners. Posner stands for a shift towards a more 'consequentialist' paradigm in legal scholarship. ${ }^{59}$ The attraction of this line of reasoning is understandable. It is undeniable that those who make legislative or judicial decisions must be sensitive to the social consequences of their actions (the impact they make on actual people's lives). If legal scholarship engages with the way those decisions affect the law, it is tempting to think that it will have to replicate this sensitivity to social consequences. The problem with this logic, however, is that it ignores the specific epistemological character of legal scholarship. It ignores what legal scholarship can do well: understanding the consequences of institutional changes for doctrinal knowledge (as opposed to understanding the impact of law on social and political changes). In fact, when it comes to the impact the law makes on society, other disciplines - and sociology and economics in particular - are far better positioned than legal scholarship. And it is certain to stay that way. Even though what these disciplines figure out about the social consequences of law are a huge inspiration for legal scholarship, we must accept a natural division of labour here. Legal scholarship must focus on what it can do better than other disciplines.

58. See, e.g., K. Llewellyn, 'Some Realism about Realism', 44 Harvard Law Review 1222, at 1249 (1931)

59. As is well known, this is a strong motive in Posner's writings - in relation to the theoretical support judges need from the academia. See, e.g., R. Posner, 'The Problematics of Moral and Legal Theory', 111 Harvard Law Review 1637 (1998). 


\section{Conclusion}

I have organised this analysis around three paradigms of interdisciplinary engagement in legal scholarship: (1) understanding better the 'footprints' of other disciplines in law, (2) managing discursive encounters that can generate frictions between disciplinary perspectives, and (3) building the knowledge base to handle challenge of validating policy initiatives for their feasibility. My claims about the paradigms were grounded in an account of the disciplinary character of legal scholarship that puts the commitment to cultivating doctrinal knowledge about the law at the centre. I have focused on the challenges legal scholars cannot tackle without communicating with other disciplines or even without building some competence in other disciplines. Legal doctrinal scholarship is in a constant need of renewing its arsenal of doctrinal constructs. Without it, it would struggle to deal with the influx of knowledge into legal scholarship from other disciplines. Interdisciplinary engagement necessitates as well as facilitates this renewal. It remains crucial for finding the adequate knowledge base for legal scholarship, as well as for enabling legal scholarship to adapt to its ever-changing social and disciplinary environment.

My analysis was only preliminary in important respects. Most importantly, I focused on demonstrating the analytical distinctions between the paradigms. That meant setting aside issues of their overlaps and intersections and the ways in which interdisciplinary engagement can move (or even have to move) from one paradigm to the other. It can turn out that philosophical accounts of corrective justice are not that supportive of the existing doctrinal structures of the law negligence. What starts off as an attempt to gain a better understanding of what is in the law may end up managing frictions between disciplinary perspectives. Managing the frictions between disciplinary perspectives can lead to challenges of institutional design, and thereby creating space for a different kind of interdisciplinary engagement. And when a policy initiative comes to be embedded in the law (like it is happening to the 'precautionary principle' in the context of environmental law right now ${ }^{60}$ ), handling policy challenges can morph into trying to understand better what is in the law already. Many important implications of my analysis can only be clarified in light of a more comprehensive analysis that factors in the complex dynamics of actual interdisciplinary scholarship. That more comprehensive analysis, however, was beyond the scope of the present paper. 